\title{
Research on Risk Factors Identification of P2P Lending Platforms
}

\author{
Caimei Lu'1, Lu Zhang² \\ ${ }^{1}$ Institute of Management and Decision, Shanxi University, Taiyuan, China \\ ${ }^{2}$ School of Economics and Management, Shanxi University, Taiyuan, China \\ Email: lucaimei@sxu.edu.cn
}

How to cite this paper: Lu, C.M. and Zhang, L. (2018) Research on Risk Factors Identification of P2P Lending Platforms. American Journal of Industrial and Business Management, 8, 1344-1357. https://doi.org/10.4236/ajibm.2018.85091

Received: April 26, 2018

Accepted: May 26, 2018

Published: May 29, 2018

Copyright (c) 2018 by authors and Scientific Research Publishing Inc. This work is licensed under the Creative Commons Attribution International License (CC BY 4.0).

http://creativecommons.org/licenses/by/4.0/

cC (i) Open Access

\begin{abstract}
We take 2259 P2P Lending platforms as the sample, and integrate 14 variables from five dimensions to analyze the risk factors of $\mathrm{P} 2 \mathrm{P}$ Lending problematic platforms by binary logistic model. The empirical results show that the 11 variables which are the type of company, platform background, operation time, the type of project, interest rate, fund custody, term of loan, day-bid, transfer of creditor's rights, automatic bidding and information disclosure, have significant influences on the operating status of the platform, while the other variables such as registered capital, the number of employees and security mechanism have no obvious impact on the operating status of the platform. The results provide a reference for investors and regulators.
\end{abstract}

\section{Keywords}

Peer-to-Peer Lending, Problematic Platform, Risk Characteristics, Binary Logistic Regression

\section{Introduction}

In recent years, online peer-to-peer (P2P) lending as an important mode of Internet finance has been developed rapidly due to its convenience and quickness. The online P2P lending refers to direct borrowing between individuals and individuals through the Internet platform. The new lending mode breaks regional restrictions and meets more small businesses and individuals' borrowing needs. The first P2P lending platform of China was set up in 2007, and then the other P2P lending platforms mushroomed rapidly.

With the rapid development of $\mathrm{P} 2 \mathrm{P}$ lending platforms, its security issues have also been widely questioned and concerned. According to the "Online Lending House" statistics, the problematic platform have shown a blowout trend since 
2013. There were 18 new problematic platforms in 2012 and before, 75 in 2013, 287 in 2014, 1156 in 2015, and 938 in 2016. By the end of 2016, the number of problem platforms had reached 2474. "Running", "fraud", "withdrawal difficult", "closed" and other problematic platforms appear frequently, which have brought great losses to investors and affected the healthy development of the industry and disrupted social order. For example, the platform "e rent treasure", which had put on a huge amount of advertising in CCTV, was investigated for illegal fund-raising at the end of 2015 and involved more than 500 billion yuan, 900 thousand investors. In January 2016, the platform "Shengshi wealth" went bankrupt, involving nearly 2 billion yuan.

Therefore, how to identify the risk factors of $\mathrm{P} 2 \mathrm{P}$ platform to reduce the loss of investors and promote the healthy development of P2P industry has become an important topic for scholars, investors and regulators. At present, most empirical researches are based on the borrower and the investor's perspective to analyze the factors affecting the rate of default loan and investment decision and few empirical studies are based on the risk of the platform. In the paper, we use the data of 2259 P2P platforms to find out the characteristic factors of the problematic platform and explore the reasons leading to the problematic platform, which will become an important supplement to the theory of P2P online lending. In addition, our research results can provide references for investors to make decisions.

\section{Literature Review}

$\mathrm{P} 2 \mathrm{P}$ lending mainly involves borrowers, investors and $\mathrm{P} 2 \mathrm{P}$ lending platforms, so the paper mainly summarizes current research from the three aspects.

\subsection{Research on Borrowers}

For the borrower's research, many scholars mainly study the influence of specific variables on the success rate of borrowing. Puro (2010) discovered the success rate of borrowing is negatively related to the amount of loans and the interest rate of borrowing [1]. Pope and Syndor (2011) found the factors that affect the success rate of loans are race, age, gender, and loan interest rate [2]. Michels (2012) thought the success rate of borrowing is related to the perfection of personal information [3]. Wang and Liao (2014) believe that the borrower's credit rating has a positive impact on the loan success rate, and has a negative impact on the cost of borrowing [4].

\subsection{Research on Investors}

The research of investors mainly focuses on investors' herding behavior, learning behavior and investment decision. Herzenstein, Dholakia and Andrews (2011) found that the herding effect is persistent and decreasing according to the data of Prosper platform [5]. Liao (2014) found that investors have a certain risk identification ability and can identify different default risks behind the same in- 
terest rate through the borrower information [6]. Liao (2016) selected peer-to-peer lending transaction data as the research sample, found that the past investment experience of the investors has a significant impact on the current investment behavior [7].

\subsection{Research on P2P Lending Platforms}

Relatively, there is less literature on the research of P2P lending platform. Huang (2015) rated financial risk of 104 platforms in China from the four aspects of credit risk, operational risk, legal compliance risk and liquidity risk [8]. Gai (2016) believed that the risk of P2P platform is mainly reflected in the platform's operation risk and financial risk. It is suggested that the regulatory framework should be set and the market innovation should be encouraged [9].

To sum up, there are more researches on borrowers and investors, and less research on P2P platforms. For the research of P2P platforms, scholars mainly conduct more qualitative analysis than quantitative analysis. Therefore, we hope to study the characteristics of platform risk by collecting a large number of platform data, so as to enrich related research contents.

\section{Research Hypothesis}

Since P2P lending research is a new field, the evaluation index system theory of P2P platform has not been established. In the paper, we construct the variables from the five dimensions of platform strength, profitability, risk control, liquidity and transparency and put forward five hypotheses.

Platform strength is described by six variables, namely, registered capital, number of employees, type of company, platform background, operation time and type of project. Registered capital and number of employees are quantitative representations of a company's size and strength. The larger the company scale, the smaller the "running" risk of platform. The company law of China divides the types of companies into limited liability companies and incorporated companies. Different types of companies have different shareholders, registered capital, and governance rules, so they include different type of risks [10]. Platform background is a symbol of the soft power of the P2P platform, which can improve the investor's expectation of platform credit, so it is an important reference factor for investors to choose the platform. Operation time reflects the operating experience of the platform, the longer the operation time, the stronger the anti-risk capability of the platform [11]. The more project types operated by the platform, the more the scope of the platform and the better the operating capacity of the platform. Therefore, we propose hypothesis 1 :

H1: The more the registered capital, the more employees, the longer the operation time and the more project type, then the better the operation status of the platform. A platform with a certain background is more secure. The impact of the type of company on platform status is unclear.

The profitability of the platform is generally measured by the annual interest 
rate, but the interest rate is proportional to the risk. Excessive interest rate implies a certain risk on the platform. The problematic platform usually attracts investors by providing high interest rate, which indicates that the platform needs a large amount of funds to fill the fund gap in the short term, or is a means to absorb funds from the fraud platform. Therefore, the high rate of return is an important manifestation of the platform risk. Based on this, the hypothesis 2 is proposed:

$\mathrm{H} 2$ : The higher the interest rate of $\mathrm{P} 2 \mathrm{P}$ platform, the greater the risk, the greater the possibility of problems.

Risk control of the platform is the most important factor for investors. The fund custody and security mechanism are the important variables that affecting the steady operation of the platform. Through third-party payment hosting and bank custody, the platform can realize the separation of own funds and investors' funds, and effectively prevent the occurrence of moral hazard and operational risk. The security mechanism of the platform provides a guarantee for the security of investors' funds, so as to prevent the platform from falling into operational difficulties due to the large amount of overdue loans. Based on this, the hypothesis 3 is proposed:

H3: The platforms with fund custody and security mechanism are more stable.

The liquidity of funds is an important index to measure the operation of the platform. It is described by four variables, including the term of loan, whether to include the day-bid, whether to support the transfer of the creditor's rights and whether to support the automatic bidding. The shorter the term of loan is, the greater liquidity risk is. When most of loan period are short-term, the platform may exist the term mismatch phenomenon and the possibility of a platform to be problematic is larger. The interest rate of day-bid is generally higher and liquidity is strong, so P2P platforms often use it to attract investors. If day-bid increases sharply in the short term, there may be dangerous signal indicating that the platform may need a lot of money and there is the possibility of "running". The mode of transfer of creditor's rights effectively improves the liquidity of funds. Automatic bidding, that is, as long as the investors set some conditions according to their own needs, the platform's system automatically matches the targets of these conditions, which improves the efficiency of the use of funds and enhances the liquidity. Therefore, the hypothesis 4 is proposed:

H4: The shorter the maturity of the platform, the greater the potential risk of the platform. The platform with day-bid has greater probability to be problematic. The operation of platform supporting the transfer of creditor's rights and automatic bidding is better.

Information disclosure mainly refers to the company's disclosure of the related information to investors and the public through various forms of reporting. Information disclosure can enable the platform to accept the supervision of the public, so that investors can fully understand the company's situation so as to protect the interests of investors. P2P lending is conducted through the net- 
work platform, so it has serious information asymmetry problem, which can easily cause adverse selection and moral hazard. The more information the platform discloses, the more standardized it is. When the information disclosure is more comprehensive and transparent, not only the financial risk of investors will be reduced, but also the platform's own credit assessment and loan pricing will be further optimized. Based on this, we put forward the hypothesis 5:

H5: The more information is disclosed, the more robust the platform runs.

\section{Data and Research Method}

\subsection{Data Sources and Sample Selection}

In the paper, the data analysis time is October 2016, so we select the platforms which set up before September 30, 2015, in order to keep the observation period of 1 year. We manually collect 2993 P2P Lending platforms from "Online Lending House" and "Online Lending Eye". For some incomplete data variables, it is mainly obtained through P2P platform website. In addition, the website of some problematic platforms has been closed, so the missing data is supplemented by reference to the "51 net loan" website. In order to ensure the accuracy of the results, we eliminate the platforms with incomplete data and finally select 2259 platforms into the analysis, including 1328 normal platforms and 931 problematic platforms.

\subsection{Research Method}

In this paper, we use the binary logistic regression model to test the above hypothesis. We select the status of the platform as the explained variables. When the platform operation is normal, the corresponding value is 0 . When the platform operation is problematic, just like "running", "closed", "withdrawal difficult" and "police involved", the corresponding value is 1 . For the explanatory variables, integrate 14 variables from five dimensions, including platform strength, profitability, risk control, liquidity and transparency to analyze the risk factors of $\mathrm{P} 2 \mathrm{P}$ Lending problematic platforms. The definition of the variables is shown in Table 1. The binary logistic regression model is as follows:

$$
y=\operatorname{logit}(p)=\ln \left(\frac{p}{1-p}\right)=\beta_{0}+\beta_{1} x_{1}+\beta_{2} x_{2}+\cdots+\beta_{14} x_{14}
$$

In the above equation, $p$ is the probability of the problematic platform, $p / 1-p$ is the ratio of the probability of the problematic platform to the normal platform. The $\beta_{0}$ is the constant term, and the $\beta_{i}$ is the coefficient of each variable in the regression equation.

\subsection{Analysis Strategy}

In order to reflect the risk factors of P2P lending platform, we establish the following model. The first step, we analyze the impact of platform strength on the operation status of the platform without considering other factors (model 1); the second step, we analyze the impact of profitability on the operation status of the 
Table 1. Description of variable.

\begin{tabular}{|c|c|c|}
\hline & Variables & Description \\
\hline & Operating status $x_{1}$ & 0 if the status was normal; 1 if the status was problematic \\
\hline \multirow{10}{*}{$\begin{array}{l}\text { Platform } \\
\text { Strength }\end{array}$} & Registered capital $\left(x_{1}\right)$ & Capital invested in registration \\
\hline & Employees $\left(x_{2}\right)$ & Number of employees employed by the company \\
\hline & & 1 if the company was Natural person Sole Corporation; \\
\hline & & 2 if the company was Corporate Owned Corporation \\
\hline & Type of company $\left(X_{3}\right)$ & Limited; 3 if the company was Natural Investment or \\
\hline & & Holding limited liability company; 4 if the company \\
\hline & & company was Incorporated Limited company \\
\hline & Background $\left(x_{4}\right)$ & $\begin{array}{l}1 \text { if the platform have a strong background(Bank, } \\
\text { state-owned assets, listed companies, venture capital); } \\
0 \text { otherwise }\end{array}$ \\
\hline & Operation time $\left(x_{5}\right)$ & effective operating time of the platform \\
\hline & Type of project $\left(x_{6}\right)$ & $\begin{array}{l}\text { The number of items such as car loan, mortgage loan, } \\
\text { personal credit loans, etc. }\end{array}$ \\
\hline Profitability & Interest rate $\left(x_{7}\right)$ & $\begin{array}{l}1 \text { if the interest rate was less than } 12 \% ; 2 \text { if the interest } \\
\text { rate was between } 12 \% \text { and } 16 \% ; 3 \text { if the interest } \\
\text { rate was between } 16 \% \text { and } 20 \% ; 4 \text { if the } \\
\text { interest rate was greater than } 20 \%\end{array}$ \\
\hline \multirow[t]{2}{*}{ Risk control } & Fund custody $\left(x_{8}\right)$ & $\begin{array}{l}1 \text { if the platform supported third-party managed funds; } \\
0 \text { otherwise }\end{array}$ \\
\hline & Security mechanism $\left(x_{9}\right)$ & 1 if the platform has a security mechanism; 0 otherwise \\
\hline \multirow{6}{*}{ Liquidity } & & 1 if the term of the loan is calculated in days; \\
\hline & & 2 if the term of the loan was mainly 3 months; \\
\hline & Term of loan $\left(x_{10}\right)$ & $\begin{array}{l}3 \text { if the term of the loan was mainly between } 4 \text { months } \\
\text { and } 6 \text { months; } 4 \text { if the term of the loan was mainly } \\
\text { between } 7 \text { months and } 12 \text { months; } 5 \text { if the term } \\
\text { of the loan was mainly over } 12 \text { months }\end{array}$ \\
\hline & Day-bid $\left(x_{11}\right)$ & 1 if the platform supported day-bid; 0 otherwise \\
\hline & $\begin{array}{l}\text { Transfer of } \\
\text { creditor's rights }\left(x_{12}\right)\end{array}$ & $\begin{array}{l}1 \text { if the platform supported transfer of } \\
\text { creditor's rights; } 0 \text { otherwise }\end{array}$ \\
\hline & Automatic bidding $\left(x_{13}\right)$ & $\begin{array}{l}1 \text { if the platform supported automatic bidding; } \\
0 \text { otherwise }\end{array}$ \\
\hline transparency & $\begin{array}{c}\text { Information } \\
\text { disclosure }\left(x_{14}\right)\end{array}$ & $\begin{array}{l}\text { The total of information disclosure items such as } \\
\text { platform profile, company information, website filing, } \\
\text { platform executive, platform fee, contact information, etc. }\end{array}$ \\
\hline
\end{tabular}

platform without considering other factors (model 2); the third step, we analyze the impact of risk control on the operation status of the platform without considering other factors (model 3); the fourth step, we analyze the impact of liquidity on the operation status of the platform without considering other factors (model 4); the fifth step, we analyze the impact of transparency on the operation status of the platform without considering other factors (model 5); the sixth step, we analyze the impact of all variables on the operation status of the platform. 


\section{Analysis of Empirical Results}

\subsection{Descriptive Statistical Analysis}

The paper makes a comparative analysis on the characteristics of normal platform and problematic platform. Table 2 shows the statistical results of numerical variables. The maximum number of employees on the normal platform is 20,000, while the maximum value of the problematic platform is only 1200 . There is a significant difference in the average number of employees between the problematic platform and the normal platform. The operation time of minimum and maximum value of normal platform is greater than that of the problematic platform, and the average operation time is more than 10 months longer than the problematic platform. The type of project for the two types of platforms is slightly different. The average information disclosure of the normal platform is higher than that of the problematic platform, and the transparency of the problematic platform is lower.

Table 3 is the statistical results of the classification variables, which mainly reflects the proportion of each index in the normal platform and the problematic platform. The most common type of company in normal platform is Natural Investment or Holding Limited Liability Company, reaching 74.1\%. The largest proportion of the problematic platform is the Natural person Sole Corporation limited liability company, reaching 56.0\%, while the Natural Investment or Holding Limited Liability Company accounts for only $38.5 \%$, which shows that the type of company has a greater impact on the platform. The proportion of the background platform in the normal platform is higher than that in the problem platform. The annual interest rate of the problem platform is generally higher than that of the normal platform. The average interest rate of the normal platform is mostly less than $16 \%$, while the interest rate of the problematic platform is between $12 \%$ - 20\%. $97.3 \%$ of the problematic platform don't support fund custody. The number of platform with a security mechanism in the normal platform is higher than that of the problematic platform. The term of loan of the

Table 2. Statistical results of numerical variables.

\begin{tabular}{|c|c|c|c|c|c|c|c|}
\hline \multirow{2}{*}{ Variables } & \multicolumn{3}{|c|}{ Normal platform (1328) } & \multicolumn{3}{|c|}{ Problematic platform (931) } & \multirow{2}{*}{$\begin{array}{c}\text { Mean } \\
\text { differences }\end{array}$} \\
\hline & minimum & maximum & mean & minimum & maximum & mean & \\
\hline $\begin{array}{l}\text { Registered capital } \\
\text { (Ten thousand yuan) }\end{array}$ & 50 & 250,000 & 5850.68 & 10 & 100,000 & 3015.44 & $2835.24^{* * *}$ \\
\hline $\begin{array}{l}\text { Employees number } \\
\text { (person) }\end{array}$ & 10 & 20,000 & 171.59 & 5 & 1200 & 56.94 & $114.65^{\star * *}$ \\
\hline $\begin{array}{l}\text { Operation time } \\
\text { (month) }\end{array}$ & 12 & 111 & 25.44 & 1 & 68 & 14.62 & $10.82^{\star * *}$ \\
\hline Type of project & 1 & 7 & 2.49 & 1 & 7 & 2.89 & $-0.40^{\star * *}$ \\
\hline $\begin{array}{c}\text { Information } \\
\text { disclosure item }\end{array}$ & 2 & 8 & 6.71 & 1 & 8 & 5.60 & $1.11^{\star * *}$ \\
\hline
\end{tabular}

Notes: ${ }^{* *},{ }^{* *}$ and ${ }^{*}$ represent $0.01,0.05$ and 0.1 levels of significance, respectively. 
Table 3. Statistical results of classification variables.

\begin{tabular}{|c|c|c|c|c|c|}
\hline Type of company & $\begin{array}{c}1: \\
\text { Natural person } \\
\text { Sole Corporation }\end{array}$ & $\begin{array}{c}2: \\
\text { Corporate } \\
\text { Owned Corporation }\end{array}$ & $\begin{array}{c}\text { 3: } \\
\text { Natural Investment } \\
\text { or Holding }\end{array}$ & $\begin{array}{c}4: \\
\text { Other } \\
\text { Limited Liability }\end{array}$ & $\begin{array}{c}5: \\
\text { Incorporated } \\
\text { Limited }\end{array}$ \\
\hline Normal & $2.4 \%$ & $12.3 \%$ & $74.1 \%$ & $6.3 \%$ & $5.0 \%$ \\
\hline Problematic & $56.0 \%$ & $2.5 \%$ & $38.5 \%$ & $1.1 \%$ & $2.0 \%$ \\
\hline Term of loan & 1: days & 2: 1 - 3 months & 3: 4 - 6 months & 4: 7 - 12 months & 5: over 12 months \\
\hline Normal & $1.4 \%$ & $17.1 \%$ & $27.0 \%$ & $37.3 \%$ & $17.3 \%$ \\
\hline Problematic & $3.7 \%$ & $56.0 \%$ & $17.0 \%$ & $14.3 \%$ & $9.1 \%$ \\
\hline Interest rate & $1:<12 \%$ & $2: 12 \%-16 \%$ & $3: 16 \%-20 \%$ & $4:>20 \%$ & \\
\hline Normal & $38.9 \%$ & $40.3 \%$ & $17.4 \%$ & $3.5 \%$ & \\
\hline Problematic & $20.3 \%$ & $23.2 \%$ & $39.2 \%$ & $17.3 \%$ & \\
\hline Security mechanism & & 0: no & 1: yes & & \\
\hline Normal & & $19.2 \%$ & $80.8 \%$ & & \\
\hline Problematic & & $31.1 \%$ & $68.9 \%$ & & \\
\hline Transfer of creditor's rights & & 0: no & 1: yes & & \\
\hline Normal & & $57.0 \%$ & $43.0 \%$ & & \\
\hline Problematic & & $91.9 \%$ & $8.1 \%$ & & \\
\hline Automatic bidding & & $0:$ no & 1: yes & & \\
\hline Normal & & $77.9 \%$ & $22.1 \%$ & & \\
\hline Problematic & & $95.4 \%$ & $4.6 \%$ & & \\
\hline Fund custody & & 0: no & 1: yes & & \\
\hline Normal & & $63.4 \%$ & $36.6 \%$ & & \\
\hline Problematic & & $97.3 \%$ & $2.7 \%$ & & \\
\hline Background & & 0: no & 1:yes & & \\
\hline Normal & & $81.6 \%$ & $18.4 \%$ & & \\
\hline Problematic & & $99.4 \%$ & $0.6 \%$ & & \\
\hline Day-bid & & $0:$ no & $1:$ yes & & \\
\hline Normal & & $68.1 \%$ & $31.9 \%$ & & \\
\hline Problematic & & $23.7 \%$ & $76.3 \%$ & & \\
\hline
\end{tabular}

normal platform is mostly distributed between 4 - 6 months and 7 - 12 months, while the problematic platform is focused on $1-3$ months and $4-6$ months, which shows that the platform with shorter term of loan is more likely to be problematic. Most problematic platforms support the day-bid. In the normal platform, the proportion of supporting transfer of creditor's rights and automatic bidding is higher than that of the problematic platform.

\subsection{Analysis of Regression Results}

As shown in Table 4, the registered capital and the number of employees in model 1 are significant at the $5 \%$ level, and after adding the other variables, that is, in model 6 , the two variables are no longer significant and the remaining variables are the same as in model 1. Profitability is significant at $1 \%$ in model 2 and model 6. In terms of risk control, the fund custody is the same level of significance in model 3 and model 6 , while the guarantee mechanism is significant in 
Table 4. Results of regression analyses.

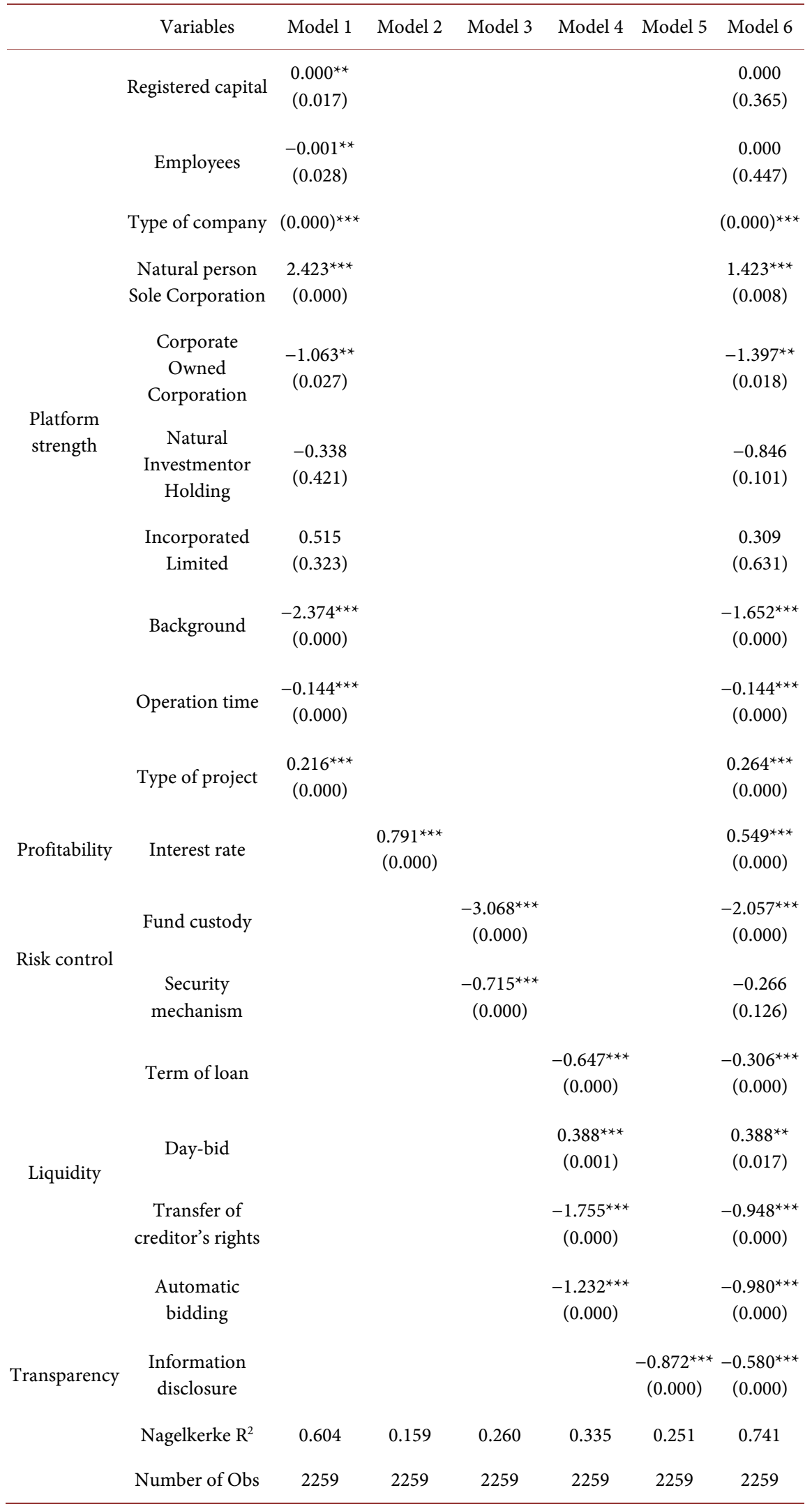

Notes: ${ }^{* *},{ }^{* *}$ and ${ }^{*}$ represent $0.01,0.05$ and 0.1 levels of significance, respectively. 
model 3, which becomes less significant in model 6 after adding other variables. The variables of liquidity are significant in model 4 and model 6 , and the significance of day-bid decreases after adding other variables. Transparency is significant both in model 5 and model 6 . In summary, the significant variables in model 6 are also significant in the first five models.

In Table 4, the $\mathrm{R}^{2}$ of model 1 (0.604) is the largest, followed by model $4\left(\mathrm{R}^{2}=\right.$ 0.335 ), the $R^{2}$ values of model 3 and model 5 are similar (0.260 and 0.251 ), and the R2 of model $2(0.159)$ is the smallest. It can be seen that the platform strength has the greatest impact on the operation status of the platform. The impact of liquidity, the impact of risk control and transparency are similar. The impact of profitability on the operation status of the platform is relatively small, which may be related to the number of variables. All variables are taken account in model 6 and $\mathrm{R}^{2}$ reaches 0.741 , which indicates that the explanatory variables can explain the variation of the explained variables to a large extent, and the fitting effect of the model is better. Therefore, the following analysis is based on the results of model 6. Specific analysis is as follows:

The registered capital and the number of employees have no significant effect on the operation status of the platform. This is inconsistent with the hypothesis, which may be caused by the structural characteristics of the sample data. It may also be due to the fact that the greater the number of registered capital and employees, the greater operational and managerial challenges.

The overall type of company has a significant impact on platform operation, and its $\mathrm{p}$ value is less than 0.001 . Specifically, the Natural person Sole Corporation limited liability company is more likely to go wrong and the Corporate Owned Corporation limited liability company is more robust. Natural person Sole Corporation Limited Liability Company shall be invested by one person, which shall be owned and controlled by the individual, and the investor shall have limited liability for the company's debts. When the actual control of the company is personal, the management transparency is relatively low and it is easy to generate the moral hazard, so the probability of such a company becoming a problem is higher. The owner of Corporate Owned Corporation Limited Liability Company is an organization whose management is more open and transparent, with a small probability of risk. The impact of Natural Investment or Holding Limited Liability Company and Incorporated Limited Company is not significant.

Platform background, operation time and project type have significant influence on the status of platform operation. Background is the symbol of soft power of the platform, and also an important index for investors to make decisions. The empirical analysis shows that there is a significant negative correlation between the platform background and the problematic platform. That is to say, background platforms are less likely to be problematic. Operation time reflects the experience of the platform and the ability to resist risks. The longer the operation time, the smaller the risk of the platform. The type of project has a posi- 
tive impact on the operation status of the platform. This is not in conformity with the hypothesis, which may be due to the more types of projects, the wider scope of the platform, and the risk management of various types of projects is not in place. What's more, some "running" platforms may have different types of projects to attract investors in order to get more money.

Interest rate has a significant impact on the operation of platform. The high interest rate is a magic weapon to attract investors and high return must be accompanied by high risk. There is a serious information asymmetry in the $\mathrm{P} 2 \mathrm{P}$ platform and investors do not know the specific operation status of the asset side. On the other hand, high borrowing rates raise the default risk of the borrowers, causing difficulties in redemption, and the platform is more likely to be in trouble.

Fund custody has a significant impact on the platform operation, while the guarantee mechanism has no significant impact on it. The fund custody is the first shield to protect the security of capital. It can effectively prevent the platform from establishing the capital pool, avoid the risk of misappropriation of funds by the platform, and protect the security of investors' funds. Security mechanism also plays a certain role in protecting investors' funds, but there are many problems with the current security model. The amount of the risk guarantee fund is limited, and the risk reserve does not match the amount of the non-performing loans of the platform. So the current security model for the protection of the platform is still limited.

Term of loan, transfer of creditor's rights and automatic bidding have significant influence on the operation of the platform, while the influence of the day-bid on the operation of the platform is weak Term of loan of the normal platform is longer and that of the problematic platform is relatively short. The long term of borrowing shows that funds are used for long-term investments, and the platform's cash flow pressure is small, which reduces the liquidity risk. Creditor's rights transfer by natural person as a lender to connect investors and borrower scan greatly improve the utilization rate of capital. Automatic bidding can automatically allocate funds to different targets through the system, save time and effort, maximize the use efficiency of funds, increase the volume of the platform and increase the liquidity. There is a weak correlation between the day-bid and the operation of platform, and some problematic platforms often issue a large number of day-bids to achieve the purpose of absorbing funds.

Information disclosure is related to the operation of platform. The more information is disclosed, the better the platform is. The more information the platform discloses, the more open and transparent the platform is, and the more standardized the operation of the platform, and it is also conducive to overall risk prevention and control. The more information is disclosed, the easier it is to gain trust from investors. Investors with professional knowledge can further analyze the actual situation of the platform so as to avoid potential risks. Meanwhile, it can also help the platform to improve and promote the healthy development of the industry. 


\subsection{Robustness Test}

In order to test the applicability of the regression model, the logistic regression of the data of platform which set up in 2012, 2013, 2014 and 2015 was conducted and compared with model 6 in Table 4. As shown in Table 5, the variables such

Table 5. 2012-2015 annual regression results.

\begin{tabular}{|c|c|c|c|c|c|c|}
\hline & \multirow{2}{*}{ variables } & 2012 & 2013 & 2014 & \multicolumn{2}{|l|}{2015} \\
\hline & & model (1) & model (2) & model (3) & model (4) & model (6) \\
\hline \multirow{10}{*}{$\begin{array}{l}\text { platform } \\
\text { strength }\end{array}$} & registered capital & $\begin{array}{c}0.000 \\
(0.972)\end{array}$ & $\begin{array}{c}0.000 \\
(0.366)\end{array}$ & $\begin{array}{c}0.000 \\
(0.987)\end{array}$ & $\begin{array}{c}0.000 \\
(0.653)\end{array}$ & $\begin{array}{c}0.000 \\
(0.365)\end{array}$ \\
\hline & employees & $\begin{array}{c}0.001 \\
(0.947)\end{array}$ & $\begin{array}{l}-0.001 \\
(0.732)\end{array}$ & $\begin{array}{c}0.000 \\
(0.895)\end{array}$ & $\begin{array}{l}-0.001 \\
(0.403)\end{array}$ & $\begin{array}{c}0.000 \\
(0.447)\end{array}$ \\
\hline & Type of company & $(0.887)$ & $(0.041)^{\star \star}$ & $(0.000)^{* * *}$ & $(0.000)^{* * *}$ & $(0.000)^{* * *}$ \\
\hline & $\begin{array}{c}\text { Natural person Sole } \\
\text { Corporation }\end{array}$ & $\begin{array}{c}0.488 \\
(1.000)\end{array}$ & $\begin{array}{l}2.823^{\star} \\
(0.076)\end{array}$ & $\begin{array}{l}3.141^{* * *} \\
(0.000)\end{array}$ & $\begin{array}{c}1.577 \\
(0.164)\end{array}$ & $\begin{array}{l}1.423^{* * *} \\
(0.008)\end{array}$ \\
\hline & $\begin{array}{c}\text { Corporate Owned } \\
\text { Corporation }\end{array}$ & $\begin{array}{l}-1.543 \\
(1.000)\end{array}$ & $\begin{array}{l}-1.533 \\
(0.632)\end{array}$ & $\begin{array}{c}0.115 \\
(0.889)\end{array}$ & $\begin{array}{l}-1.584 \\
(0.223)\end{array}$ & $\begin{array}{c}-1.397^{\star *} \\
(0.018)\end{array}$ \\
\hline & $\begin{array}{c}\text { Natural Investmentor } \\
\text { Holding }\end{array}$ & $\begin{array}{c}0.428 \\
(1.000)\end{array}$ & $\begin{array}{l}-1.060 \\
(0.373)\end{array}$ & $\begin{array}{c}0.238 \\
(0.733)\end{array}$ & $\begin{array}{l}-0.199 \\
(0.855)\end{array}$ & $\begin{array}{l}-0.846 \\
(0.101)\end{array}$ \\
\hline & Incorporated Limited & $\begin{array}{c}1.847 \\
(1.000)\end{array}$ & $\begin{array}{l}-3.243 \\
(0.786)\end{array}$ & $\begin{array}{l}-2.132 \\
(0.928)\end{array}$ & $\begin{array}{c}0.231 \\
(0.903)\end{array}$ & $\begin{array}{c}0.309 \\
(0.631)\end{array}$ \\
\hline & Background & $\begin{array}{c}-18.662 \\
(0.998)\end{array}$ & $\begin{array}{c}-18.904 \\
(0.997)\end{array}$ & $\begin{array}{l}-0.998^{*} \\
(0.076)\end{array}$ & $\begin{array}{l}-2.506^{*} \\
(0.063)\end{array}$ & $\begin{array}{c}-1.652^{* * *} \\
(0.000)\end{array}$ \\
\hline & Operation time & $\begin{array}{c}-0.121^{\star *} \\
(0.019)\end{array}$ & $\begin{array}{c}-0.798^{\star * *} \\
(0.000)\end{array}$ & $\begin{array}{c}-0.319^{* * *} \\
(0.000)\end{array}$ & $\begin{array}{c}-0.677^{\star * *} \\
(0.000)\end{array}$ & $\begin{array}{c}-0.144^{\star * *} \\
(0.000)\end{array}$ \\
\hline & Type of project & $\begin{array}{l}0.859^{*} \\
(0.093)\end{array}$ & $\begin{array}{c}0.054 \\
(0.874)\end{array}$ & $\begin{array}{c}0.363^{* * *} \\
(0.000)\end{array}$ & $\begin{array}{l}0.369^{* * *} \\
(0.005)\end{array}$ & $\begin{array}{c}0.264^{\star * *} \\
(0.000)\end{array}$ \\
\hline Profitability & Interest rate & $\begin{array}{c}0.512 \\
(0.436)\end{array}$ & $\begin{array}{c}0.106 \\
(0.830)\end{array}$ & $\begin{array}{l}0.376^{\star * \star} \\
(0.003)\end{array}$ & $\begin{array}{l}0.552^{* * *} \\
(0.007)\end{array}$ & $\begin{array}{l}0.549^{* * *} \\
(0.000)\end{array}$ \\
\hline \multirow{3}{*}{ risk control } & Fund custody & $\begin{array}{c}-17.415 \\
(0.999)\end{array}$ & $\begin{array}{l}-2.108 \\
(0.159)\end{array}$ & $\begin{array}{c}-2.170^{* * *} \\
(0.000)\end{array}$ & $\begin{array}{c}-1.288^{* * *} \\
(0.004)\end{array}$ & $\begin{array}{c}-2.057^{* * *} \\
(0.000)\end{array}$ \\
\hline & Security mechanism & $\begin{array}{c}0.063 \\
(0.963)\end{array}$ & $\begin{array}{l}-2.298 \\
(0.151)\end{array}$ & $\begin{array}{c}0.086 \\
(0.752)\end{array}$ & $\begin{array}{c}0.576 \\
(0.221)\end{array}$ & $\begin{array}{l}-0.266 \\
(0.126)\end{array}$ \\
\hline & Term of loan & $\begin{array}{l}-0.293 \\
(0.602)\end{array}$ & $\begin{array}{l}-0.019 \\
(0.959)\end{array}$ & $\begin{array}{l}-0.215^{* *} \\
(0.047)\end{array}$ & $\begin{array}{l}-0.365^{* *} \\
(0.027)\end{array}$ & $\begin{array}{c}-0.306^{* * *} \\
(0.000)\end{array}$ \\
\hline \multirow{2}{*}{ liquidity } & Day-bid & $\begin{array}{l}2.794^{\star *} \\
(0.031)\end{array}$ & $\begin{array}{l}2.611^{*} \\
(0.055)\end{array}$ & $\begin{array}{l}0.495^{*} \\
(0.060)\end{array}$ & $\begin{array}{c}0.343 \\
(0.330)\end{array}$ & $\begin{array}{l}0.388^{\star *} \\
(0.017)\end{array}$ \\
\hline & $\begin{array}{c}\text { Transfer of creditor's } \\
\text { rights }\end{array}$ & $\begin{array}{l}-0.838 \\
(0.612)\end{array}$ & $\begin{array}{l}-1.155 \\
(0.230)\end{array}$ & $\begin{array}{c}-0.772^{\star \star \star} \\
(0.006)\end{array}$ & $\begin{array}{c}-1.674^{\star * *} \\
(0.001)\end{array}$ & $\begin{array}{c}-0.948^{\star * *} \\
(0.000)\end{array}$ \\
\hline \multirow{4}{*}{ transparency } & automatic bidding & $\begin{array}{l}3.202^{\star *} \\
(0.085)\end{array}$ & $\begin{array}{l}-1.467 \\
(0.263)\end{array}$ & $\begin{array}{c}-2.469^{* * *} \\
(0.000)\end{array}$ & $\begin{array}{c}0.057 \\
(0.909)\end{array}$ & $\begin{array}{c}-0.980^{\star * *} \\
(0.000)\end{array}$ \\
\hline & $\begin{array}{l}\text { information } \\
\text { disclosure }\end{array}$ & $\begin{array}{c}-1.498^{\star *} \\
(0.021)\end{array}$ & $\begin{array}{l}-0.437 \\
(0.169)\end{array}$ & $\begin{array}{c}-0.281^{\star *} \\
(0.012)\end{array}$ & $\begin{array}{c}-0.943^{\star * *} \\
(0.001)\end{array}$ & $\begin{array}{c}-0.580^{* * *} \\
(0.000)\end{array}$ \\
\hline & Nagelkerke $\mathrm{R}^{2}$ & 0.851 & 0.944 & 0.784 & 0.859 & 0.741 \\
\hline & Number of Obs & 96 & 335 & 1115 & 713 & 2259 \\
\hline
\end{tabular}

Notes: ${ }^{* *},{ }^{* *}$ and ${ }^{*}$ represent $0.01,0.05$ and 0.1 levels of significance, respectively. 
as registered capital, employees and the security mechanism are not significant in model 6, and the regression results are also not significant in each year. The significant variables in model 6 are still significant in the regression results of 2014, and some of them are significantly lower. In the regression results of 2015, only the two variables of security mechanism and day-bid are no longer significant. In 2012 and 2013, due to the small number of platforms, there are less significant variables in the regression results. In general, the model is still applicable to most platforms, and the model is robust.

\section{Conclusion}

We select the basic data from 2259 P2P Lending platforms published by "Online Lending House" and "Online Lending Eye" as the sample, integrate 14 variables from five dimensions, and use the binary logistic regression method to study the risk characteristics of $\mathrm{P} 2 \mathrm{P}$ platform. The results show that the platform strength, profitability, risk control, liquidity and transparency can predict the probability of the platform becoming problematic. The platforms of Natural person Sole Corporation Limited Liability Company are more likely to be problematic. Background platforms are less likely to be problematic. The longer the operation time and the fewer type of project, the better the operation of the platform. The platform with higher interest rate is more likely to be problematic, while platforms with fund custody are less likely to be problematic. The shorter the loan period is, the greater the platform risk is. The platform which supports creditor's rights transfer and automatic bidding has less liquidity risk and better operation. The more information disclosure the platform has, the more standardized it is. The conclusions of this paper can provide references for investors and regulators. Compared with historical documents, the paper first proposes the type of company as an important risk characteristic variable of $\mathrm{P} 2 \mathrm{P}$ platform and uses a large sample to analyze the platform risks quantitatively, and thus complements the existing literature.

\section{Foundation}

Supported by Program for the Philosophy and Social Sciences Research of Higher Learning Institutions of Shanxi (PSSR) under Grant No. 2016305.

\section{References}

[1] Puro, L., Teich, J., Wallenius, H. and Wallenius, J. (2010) Borrower Decision Aid for People-to-People Lending. Decision Support Systems, 49, 52-60. https://doi.org/10.1016/j.dss.2009.12.009

[2] Pope, D.G. and Sydnor J.R. (2011) What's in a Picture? Evidence of Discrimination from Prosper.com. Journal of Human Resources, 46, 53-92. https://doi.org/10.1353/jhr.2011.0025

[3] Michels, J. (2012) Do Unverifiable Disclosures Matter? Evidence from Peer-to-Peer Lending. The Accounting Review, 87, 1385-1413. https://doi.org/10.2308/accr-50159 
[4] Wang, H.J. and Liao, L. (2014) China's P2P Platform's Credit Authentication Mechanism Research: Evidence from Renrendai. China Industrial Economics, 31, 136-147.

[5] Herzenstein, M., Dholakia, U.M. and Andrews, R. (2011) Strategic Herding Behavior in Peer-to-Peer Loan Auctions. Journal of Interactive Marketing, 25, 27-36. https://doi.org/10.1016/j.intmar.2010.07.001

[6] Liao, L., Li, M.R. and Wang, Z.W. (2014) The Intelligent Investors: Not-Fully-Marketized Interest Rate and Risk Identify. Economic Research, 60, 125-137.

[7] Wang, Z.W., Xiang, J. Liao, L., and Zhang W.Q. (2016) Economic Analysis of Investors Learning Behavior under the Environment of Internet Finance. The Journal of Quantitative \& Technical Economics, 32, 95-111.

[8] Huang, G.P. and Wu, X.C. (2015) Report on the Development of China's P2P Lending (2014-2015). Social Science Literature Press, Beijing.

[9] Gai, J. (2016) Where Is P2P's Future Development and Regulatory Path? Credit Reporting, 22, 9-14.

[10] Wang, B.S. (2012) The Trend of Corporate Legal Structure Reform. China Legal Science, 28, 106-116.

[11] Li, X.L. (2015) An Empirical Analysis of the Reasons for the Failure of P2P Lending Platform. Journal of Financial Development Research, 33, 51-55. 